\title{
Nine cases of gastric ulcer after vagotomy and drainage for duodenal ulcer
}

\author{
SIMMY BANK, I. N. MARKS, J. H. LOUW, AND B. BROM \\ From the Gastrointestinal Unit, Groote Schuur Hospital, and the Departments of Medicine and \\ Surgery, University of Cape Town
}

Gastric ulceration was recognized as an occasional complication of vagotomy soon after Dragstedt championed the operation for the treatment of duodenal ulceration (Dragstedt and Owens, 1943). Gastric atony and antral stasis were to be expected after vagotomy without adequate drainage of the gastric contents and it was perhaps not surprising that a number of patients should have developed lesser curve gastric ulceration after vagotomy alone. The mechanism responsible for the development of gastric ulceration in these circumstances was later considered to be due to gastric retention, antral stasis and alkalinization, and gastrin release, with the resulting continual gastric acid stimulation (Dragstedt, 1953; Burge, 1964; Oberhelman, 1964). The occurrence of gastric ulceration after vagotomy lent further support to Dragstedt's well known postulate that all gastric ulceration was dependent on the hormonal phase of gastric secretion consequent upon antral stasis and 'hyperfunction or dysfunction of the gastric antrum' (Dragstedt, 1953, 1956). Other workers have not noted a significant difference in gastric emptying between duodenal and gastric ulcer patients (Buchler, 1964; Griffith, Owen, Campbell, and Shields, 1968).

Vagotomy combined with an adequate and truly dependent drainage procedure was found to prevent, or in fact heal, gastric ulceration (Dragstedt, 1952; Burge, 1964, 1966). This led many workers to consider the drainage procedure to be the most important single procedure in effecting healing of these gastric ulcers, the vagotomy serving to reduce the vagal and antral phase of acid secretion. It also explained the excellent results with gastroenterostomy alone in the treatment of gastric ulceration in many patients. Recently Burge and others have revived vagotomy and drainage as a curative operation for lesser curve gastric ulcers and Burge reiterated the importance of adequate drainage (Burge, 1964, 1966; Dragstedt, 1966; Kennedy and George, 1967).

Since the adoption of vagotomy and drainage, either gastroenterostomy and more recently the popular operation of pyloroplasty, as the operation of choice for duodenal ulcer in the majority of surgical centres, little has been written about recurrent gastric ulceration after these procedures (Bockus, 1964; Burge, 1964; Stitt, O’Sullivan, and Currie, 1966). Most attention has been directed to the incidence of recurrent jejunal or duodenal ulceration and their relationship to incomplete vagal section (Burge, 1964; Ross and Kay, 1964; Bank, Marks, and Louw, 1967). Burge (1964) tends to disregard gastric ulceration after vagotomy and drainage, dismissing its occurrence as due to an inadequate drainage procedure or to transient gastric stasis caused by a denervated stomach, the ulcer healing as gastric tone recovers.

The purpose of the present paper is to present nine patients who developed gastric ulceration after vagotomy and drainage for duodenal ulceration, and to emphasize the importance of considering this occasional development in patients with recurrent dyspepsia or bleeding despite a seemingly adequate drainage procedure and an apparently complete vagotomy.

\section{CASE REPORTS}

CASE 1 A woman aged 60 was admitted for elective surgery for duodenal ulceration. She had a long history of periodic ulcer dyspepsia with a recent story of intractibility, nocturnal waking, and back pain. There was also a history of melaena stools in the past.

On examination she had mild rheumatoid arthritis of the hands and the peripheral blood vessels were palpable. Her blood pressure was moderately elevated at $180 \mathrm{~mm}$ $\mathrm{Hg}$ systolic and $100 \mathrm{~mm} \mathrm{Hg}$ diastolic and she had a grade 2 aortic systolic murmur. The rest of the examination contributed nothing. The blood count and serum chemistry were normal. Barium meal examination showed a grossly deformed duodenal cap, the stomach being normal. Acid secretory studies were inadvertently not done.

A truncal vagotomy and two-layer pyloroplasty was carried out and her postoperative course was uneventful. 
The nasogastric tube was removed on the third day and she returned to a full diet thereafter. Except for mild temporary dysphagia over the next few days there were no symptoms of gastric retention, dumping, diarrhoea, or indigestion. The patient was discharged to a convalescent home for a few weeks.

A severe haematemesis three weeks after her operation necessitated an emergency readmission to the hospital. During the three weeks she had been taking occasional acetylsalicylic acid compounds for her arthritis. Blood transfusions were given with a satisfactory circulatory response and it was thought that the bleeding was precipitated by aspirin. The day after admission she had a massive haematemesis and died despite rescuscitative measures. Necropsy showed a bleeding subacute lesser curve gastric ulcer.

CASE 2 A woman aged 59 was admitted for elective surgery for a duodenal ulcer. She gave a three-year history of periodic ulcer dyspepsia which lately had not responded to alkali therapy. In addition, during the last three months vomiting, loss of weight, and loss of appetite had become prominent. Previous barium meal examinations had confirmed the presence of a duodenal ulcer.

Examination showed a rather obese woman with a blood pressure of $170 \mathrm{~mm} \mathrm{Hg}$ systolic and 100 diastolic. The physical examination was otherwise normal, as was her blood count. Acid secretory studies showed a basal secretion of $7.4 \mathrm{~m}$-equiv/hour and a maximal acid output (MAO) of $20 \cdot 2 \mathrm{~m}$-equiv/hour.

A truncal vagotomy and one-layer pyloroplasty was carried out. A splenectomy had to be performed due to damage to the spleen at surgery. There were no postoperative complications, her course in hospital was smooth, and she was discharged on the tenth day after operation.
She remained perfectly well for six months but then experienced dyspeptic symptoms again. On this occasion the symptoms occurred about 30 minutes after a meal and the resident who saw her initially made a confident diagnosis of 'gastric ulceration'. Vomiting relieved her symptoms as did alkalis.

Examination revealed a well-looking woman with a blood pressure of $200 \mathrm{~mm} \mathrm{Hg}$ systolic and 100 diastolic. She had bilateral varicose veins and there was tenderness to deep pressure in the epigastrium. Tests for occult blood in the stools were negative: haemoglobin was $11.5 \mathrm{~g} \%$; white cell count 6,800 per $\mathrm{c} \mathrm{mm}$ and sedimentation rate $6 \mathrm{~mm} /$ hour (Westergren). A barium meal showed a lesser curve gastric ulcer which was confirmed by gastroscopy (Fig. 1). An augmented histamine test now showed a basal secretion of $4.5 \mathrm{~m}$-equiv/hour and MAO of $10 \mathrm{~m}$-equiv/hour. Treatment with carbenoxolone, alkalis, anticholinergics, and bed rest was commenced and her symptoms rapidly subsided. A barium meal carried out after two weeks showed no evidence of ulceration but gastrocamera examination revealed that the ulcer, although much smaller, was still present. Gastritic changes were thought to be present in the antrum and around the ulcer. The development of deep venous thrombosis in the right leg delayed her discharge. Her blood pressure, electrolytes, and electrocardiograph were unchanged at the time of her discharge one month after admission. A gastrocamera study carried out six weeks later showed a tiny healing ulcer, and she is at present on maintenance carbenoxolone therapy.

CASE 3 A woman aged 43 was subjected to elective surgery for a 10-year history of duodenal ulcer dyspepsia recently intractable. The basal acid secretion was $1.5 \mathrm{~m}$-equiv/hour and the MAO $13 \mathrm{~m}$-equiv/hour. A truncal vagotomy and Finney pyloroplasty was carried

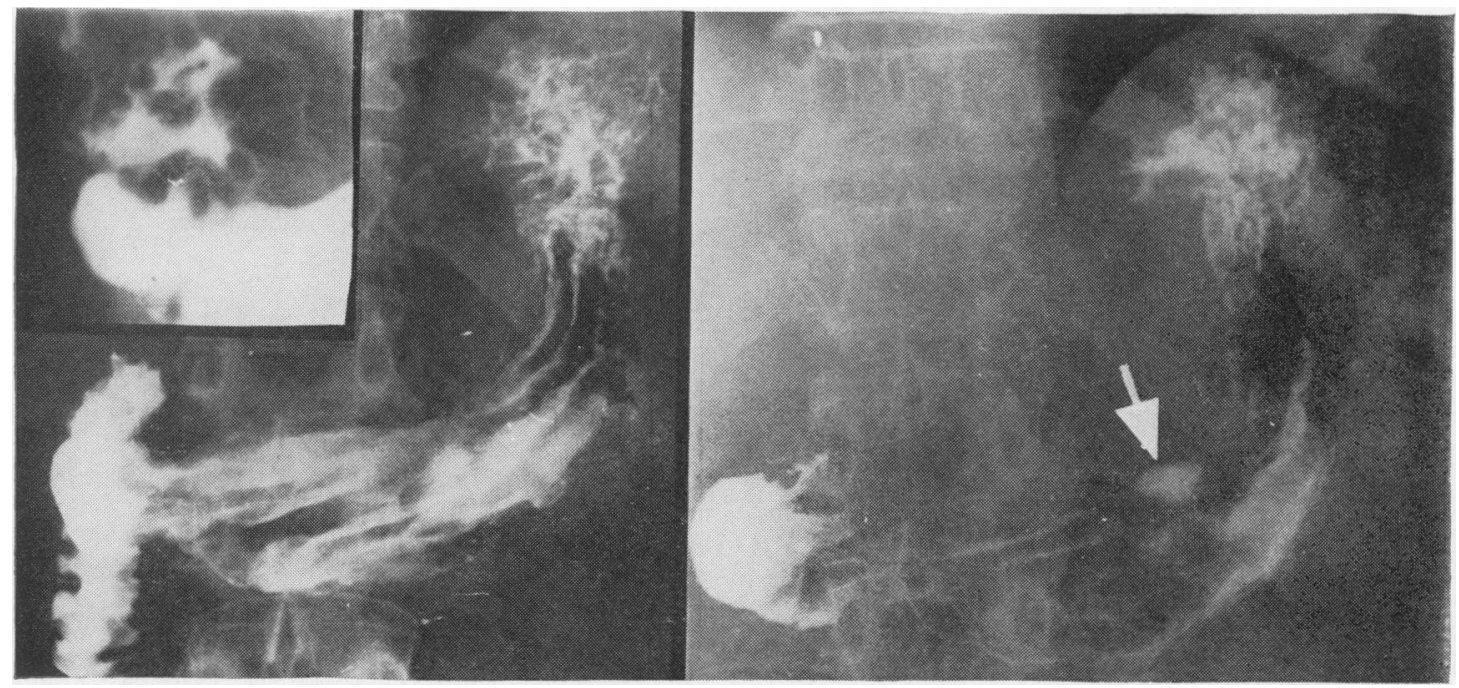

FIG. 1. Radiographs during barium meal examinations before and six months after vagotomy and pyloroplasty in a 59-year-old woman showing a large gastric ulcer on the lesser curve. 
out in May 1966. Postoperatively she experienced transient dysphagia, symptoms of retention, waterbrash, and diarrhoea and was readmitted for symptoms of gastric retention some two weeks after her discharge. This was treated with nasogastric suction and intravenous therapy for a few days. Four months after operation the symptoms were greatly improved and her basal secretion was $1.4 \mathrm{~m}$-equiv/hour and MAO $2.5 \mathrm{~m}$-equiv/hour.

In January 1967, six months after operation, she again complained of mild dysphagia and retention but now had, in addition, epigastric pain. A barium meal examination suggested a lesser curve gastric ulcer and this was confirmed at gastroscopy (Fig. 2). Treatment with alkalis and anticholinergics produced a rapid improvement in the symptoms for three months but a recurrence of symptoms, loss of weight, flatulence, and regurgitation of food prompted reinvestigation 13 months after her operation. Barium meal again showed a gastric ulcer which was confirmed on gastroscopy. Her basal acid secretion was now 2 m-equiv/hour and the MAO 3.1 $\mathrm{m}$-equiv/hour and an insulin test was negative indicating a complete vagotomy. A Billroth II gastrectomy was carried out in June 1967 and she has remained well since. Gastritis was evident on microscopy of the resected stomach.

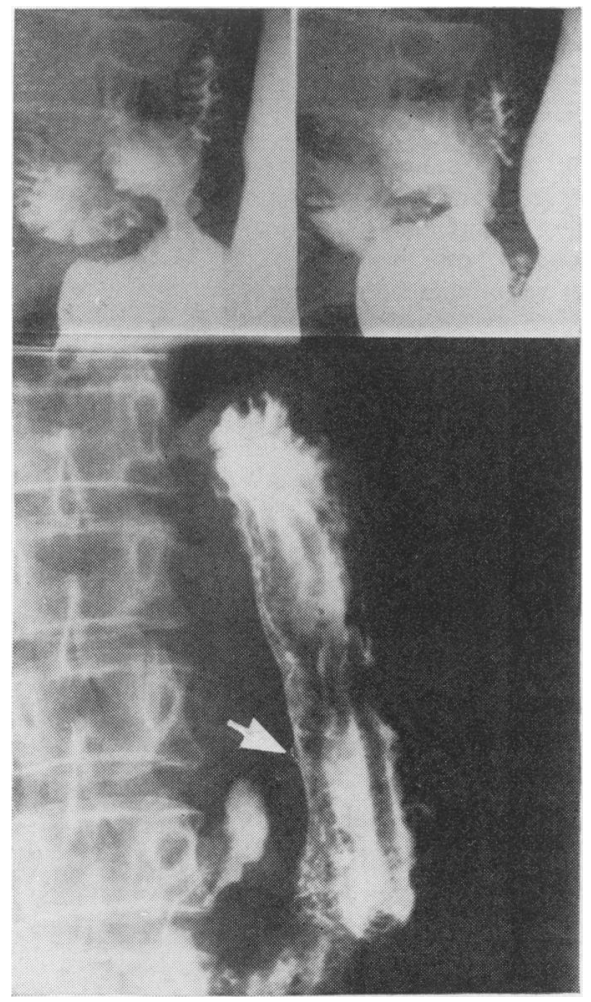

FIG. 2. Radiographs during barium meal examinations before and six months after vagotomy and pyloroplasty in case 3.
CASE 4 A 46-year-old woman was subjected to elective surgery for an eight-year history of duodenal ulcer corroborated by three separate barium meal examinations. A truncal vagotomy and Heineke-Mikulicz pyloroplasty was performed for a chronic duodenal ulcer in July 1967. The postoperative course was uneventful and she was discharged on the seventh postoperative day. Gastric acid studies were not carried out before operation. She was asymptomatic when seen again one month after surgery and a routine augmented histamine test showed some gastric retention, a basal acid output of 2.5 m-equiv/ hour, and MAO of 2 m-equiv/hour.

Abdominal pain and vomiting recurred three months after operation necessitating the giving of alkalis and tranquillizers with some relief. However, two months later, the abdominal pain became persistent, she experienced relief from vomiting, and had a brisk haematemesis. There was epigastric tenderness on examination. She was again given medical treatment but returned three months later with similar symptoms and was then investigated again.

Acid secretory studies still showed some retention, the basal acid secretion being $2 \mathrm{~m}$-equiv/hour, and MAO 2.9 m-equiv/hour. Two separate insulin tests showed a negative response to 15 units of intravenous insulin. A barium meal was inconclusive but suggested the possibility of a recurrent ulcer. Gastrocamera studies showed a small prepyloric ulcer with surrounding erythema. She was put onto extensive alkali and anticholinergic treatment with only partial improvement. Gastrectomy is at present being contemplated.

CASE 5 A woman aged 46 was subjected to elective surgery for a five-year history of ulcer dyspepsia and a three-week history of back pain, loss of appetite, and loss of weight. A barium meal showed a large duodenal ulcer with associated spasm. Her basal acid secretion was $0.3 \mathrm{~m}$-equiv/hour and MAO 7.2 m-equiv/hour.

A selective vagotomy and single-layer pyloroplasty was carried out in March 1965. Her hospital stay was protracted to 18 days because of postoperative vomiting, eructation, and diarrhoea. These symptoms seemed to have subsided at the time of discharge but her acid secretory studies were of interest in that the basal secretion was now 3.9 m-equiv/hour and MAO 8.5 m-equiv/hour.

She was readmitted 24 days after discharge with epigastric pain. Examination showed the outline of a dilated stomach through a thin abdominal wall. The clinical impression of gastric stasis was confirmed on barium meal and in addition there was a large gastric ulcer on the lesser curve of the stomach (Fig. 3). Nasogastric suction and intravenous therapy caused a rapid improvement in her symptoms and the ulcer was confirmed gastroscopically thereafter. Her basal secretion was $0 \mathrm{~m}$-equiv/hour and MAO $1 \cdot 1 \mathrm{~m}$-equiv/hour at this stage.

Treatment with carbenoxolone, antacids, and anticholinergics was started and continued for six weeks. Repeated barium meals showed a gradual reduction in ulcer size but she refused gastroscopy or gastrocamera studies. Treatment was continued for three months at 


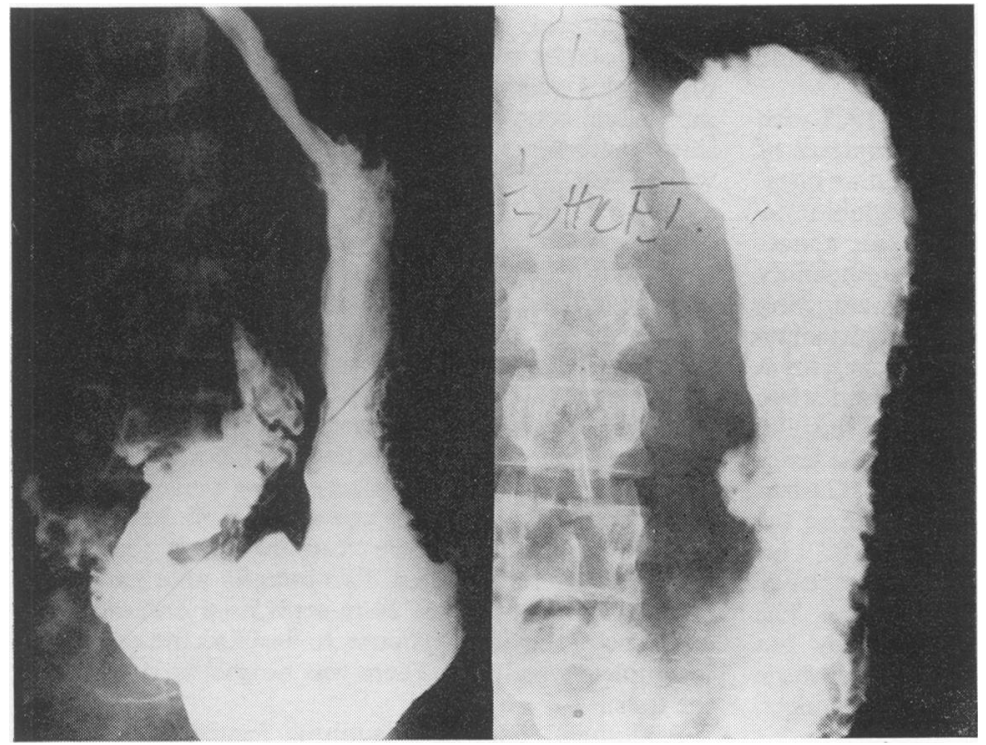

FIG. 3. Barium meal examination before and three weeks after vagotomy and pyloroplasty in a 46-yearold woman showing a large gastric ulcer on the lesser curve.

which time she was placed on maintenance carbenoxolone therapy. There has been no recurrence after one and a half years.

CASE 6 A man aged 50 was admitted in January 1965 with a four-month history of periodic ulcer dyspepsia culminating in melaena five days before admission. He had a long history of heavy drinking but had stopped drinking for two years following an episode of jaundice. In addition, a suspected perforated ulcer had been treated conservatively one year before.

On examination his blood pressure was 130 systolic and 80 diastolic. There were spider naevae over the chest and neck, palmar erythema, and a firm hepatomegaly of 4 fingerbreadths. The haemoglobin was $13 \%$, sedimentation rate $15 \mathrm{~mm} / \mathrm{hr}$ (Westergren), and the white cell count 8,000 per $\mathrm{c} \mathrm{mm}$. The serum bilirubin was $2 \cdot 1 \mathrm{mg} \%$, alkaline phosphatase $14.5 \mathrm{~K}-\mathrm{A}$ units, and the serum albumin and globulin were both $3 \cdot 2 \mathrm{~g} \%$. Stool occult blood tests were strongly positive. A few days after admission he developed signs of porto-systemic encephalopathy with confusion and disorientation which responded slowly to protein restriction and neomycin therapy. After recovery a barium meal showed a duodenal ulcer in a scarred contracted cap but there were no oesophageal varices and the stomach was normal. A cholecystogram, carried out when the bilirubin level was normal, failed to show dye in the gallbladder. A secretin-pancreozymin pancreatic function test was grossly abnormal and considered to represent 'alcoholic pancreatopathy'. His basal acid secretion was $3.2 \mathrm{~m}$-equiv/hour and the MAO 57.1 m-equiv/hour. As tests for occult blood remained positive surgical treatment was recommended. Laparotomy revealed a large duodenal ulcer, gallstones, pancreatitis, and a large 'hob-nail' liver.

A truncal vagotomy and posterior gastroenterostomy was carried out but cholecystectomy was considered hazardous and the gallbladder was not removed. The postoperative course was uneventful apart from mild fullness after meals and he was discharged on the 14th day. His acid secretion one month after surgery was still high, the basal value being $2 \mathrm{~m}$-equiv/hour and the MAO 35.5 m-equiv/hour despite an apparently complete vagotomy on insulin testing.

He remained well for two and a half months but was readmitted with a two-day history of epigastric pain followed by haematemesis and melaena. On examination the signs of cirrhosis were unchanged but he was jaundiced, confused, and had a flapping tremor. The haemoglobin was $9.7 \%$, PCV 27, white blood count 13,000 per $\mathrm{cmm}$, and platelets 166,000 per $\mathrm{c} \mathrm{mm}$. He received 8 pints of blood initially and it was thought that the duodenal ulcer had become reactivated or that he now had oesophageal varices. An emergency barium meal in the ward revealed the presence of a lesser curve gastric ulcer but before surgery could be contemplated he had two massive haematemeses, lapsed into deep hepatic coma, and died. Necropsy confirmed the presence of gastric ulcer, a duodenal scar, and cirrhosis.

CASE 7 A man aged 34 was subjected to elective surgery for duodenal ulceration. He had a four-year history of ulcer dyspepsia which was recently complicated by back pain and loss of weight. Barium examination showed an 'active duodenal ulcer'. He was a heavy drinker and had been advised to give up alcohol. Acid secretory studies showed a basal value of $0.9 \mathrm{~m}$-equiv/hour and MAO of 29.9 m-equiv/hour. A pancreatic function test was normal.

A truncal vagotomy and single-layer pyloroplasty was carried out in February 1966 for an active anterior duodenal ulcer which was extending onto the lesser curve of the duodenum. His postoperative course was smooth. 
In particular, there were no symptoms of retention or gastrointestinal upset, and he was discharged on the tenth day.

He was readmitted to hospital in February 1968 with a history of melaena stools. There were no symptoms of dyspepsia, heartburn, retention, dumping, or diarrhoea. His general condition was good and the haemoglobin was $14 \%$. A barium meal examination showed an abnormality in the region of the pyloroplasty and the possibility of a recurrent duodenal ulcer was raised. Gastric emptying of barium was normal. A repeated augmented histamine test showed a basal value of $1.2 \mathrm{~m}$-equiv/hour and a MAO of 4.9 m-equiv/hour. An insulin test showed a late positive response in the second hour after insulin. Gastroscopy failed to reveal any ulceration but the lesser curve of the antrum could not be visualized. Gastrocamera studies were unfortunately not available at the time.

While he was in the hospital he had a further episode of melaena and a laparotomy was undertaken. The pyloroplasty was wide and functioning normally but a thickened area could be palpated in the prepyloric region. Gastrotomy revealed a prepyloric chronic ulcer, and a Polya gastrectomy was done.

CASE 8 A man aged 38 was admitted for elective surgery for a proven duodenal ulcer. Ulcer symptoms had been present for 12 years, recently intractable, and loss of weight. Physical examination was normal but the haemoglobin was moderately low at $11.5 \%$. His basal acid secretion was 5.4 m-equiv/hour and the MAO was $40 \mathrm{~m}$-equiv/hour. A selective vagotomy and single-layer pyloroplasty was carried out in July 1964 and the postoperative course was uneventful. A postoperative augmented histamine test showed a basal value of 8.4 m-equiv/hour and MAO of $12.9 \mathrm{~m}$-equiv/hour two months after operation.

He remained well for about six months and then complained of postprandial dyspepsia once again. Barium meal showed a well functioning pyloroplasty but no lesion in the stomach; in particular there was no gastric retention or ulceration. An augmented histamine test carried out 14 months after operation again showed a high basal value of $8.9 \mathrm{~m}$-equiv/hour and MAO of $14.5 \mathrm{~m}$-equiv/hour. The acid secretion was effectively reduced by propantheline to levels of $2.7 \mathrm{~m}$-equiv/hour and $8.2 \mathrm{~m}$-equiv/hour MAO and he was maintained on anticholinergics. An insulin test showed a high basal value with a positive response to insulin in the second hour after insulin only.

He was readmitted in April 1967 with a five-day history of severe right upper quadrant pain, unrelieved by alkalis, vomiting of altered blood, and upper abdominal distension. There was guarding and tenderness in the right upper quadrant but a radiograph of the abdomen failed to show free intraperitoneal air. He was treated with nasogastric suction and an intravenous drip for four days and a tentative diagnosis of recurrent duodenal ulceration with subacute perforation was made.

Laparotomy showed that the duodenum was adherent to the under surface of the liver at the site of the old, adequately functioning pyloroplasty and thickening of the prepyloric area. A Polya gastrectomy was done. Examination of the resected stomach showed an antral or prepyloric ulcer $1.7 \mathrm{~cm}$ in diameter and penetrating the muscle coat of the stomach. He has remained well since gastrectomy, the only side effect being some initial weight loss.

CASE 9 A 42-year-old man was subjected to surgery for a chronic postbulbar duodenal ulcer in February 1967. He had suffered one episode of gastrointestinal bleeding previously. A preoperative augmented histamine test showed a basal value of $2 \cdot 2 \mathrm{~m}$-equiv/hour and MAO of 39.5 m-equiv/hour.

Surgery confirmed the presence of a large postbulbar ulcer and an anterior selective and posterior truncal vagotomy and a pyloroplasty were performed. The postoperative course was uneventful and he was discharged to attend the gastrointestinal clinic for routine postoperative acid studies. Two months after surgery he still had a high MAO of $24 \mathrm{~m}$-equiv/hour and there was a distinct positive response to insulin, indicating an incomplete vagotomy. There was no gastric retention in the tests.

Abdominal pain and vomiting recurred 10 months after his operation, responded mildly to ulcer therapy, and became progressively more severe. A barium meal in July 1968 showed a deformed pylorus and a possible ulcer niche in the pyloric area. The presence of a prepyloric gastric ulcer was confirmed by fibre gastroscopy, and therapy has been started with maintenance doses of Biogastrone.

\section{RESULTS}

There were five females and four males in the present series and their ages ranged from 34 to 60 years with a mean of 47 years (Table I). The operations for duodenal ulcer were as follows: selective vagotomy and pyloroplasty in three cases, truncal vagotomy and pyloroplasty in five, and truncal vagotomy and gastroenterostomy in the remaining one. Postoperatively two patients had evidence of marked gastric stasis and one had mild fullness after meals. Clinical evidence of recurrent ulceration appeared within three weeks to two years. The ulcer was situated on the lesser curve in five cases and in the antrum or prepyloric area in four. Three patients presented with massive bleeding and two succumbed; one of the latter patients had been taking salicylates and the other had advanced cirrhosis of the liver. The remaining six patients had typical ulcer dyspepsia or atypicalabdominal pain associated with radiological, endoscopic, or operative evidence of chronic gastric ulceration. Two patients responded to medical treatment and are at present on maintenance carbenoxolone therapy, three were subjected to gastrectomy for recurrent symptoms after initial clinical improvement with medical therapy, and the remaining two, with recent onset of symptoms, are 
TABLE I

DATA ON NINE PATIENTS WITH GASTRIC ULCER FOLLOWING VAGOTOMY AND DRAINAGE

\begin{tabular}{|c|c|c|c|c|c|c|c|c|c|c|c|c|c|c|}
\hline \multirow{3}{*}{$\begin{array}{l}\text { Case } \\
\text { No. }\end{array}$} & \multirow{3}{*}{$\operatorname{Sex}$} & \multirow{3}{*}{ Age } & \multirow{3}{*}{$\begin{array}{l}\text { Type of } \\
\text { Operation }\end{array}$} & \multirow{3}{*}{$\begin{array}{l}\text { Symptoms } \\
\text { after } \\
\text { Operation }\end{array}$} & \multirow{3}{*}{$\begin{array}{l}\text { Interval } \\
\text { between } \\
\text { Operation } \\
\text { and Onset } \\
\text { of Gastric } \\
\text { Ulcer }\end{array}$} & \multicolumn{3}{|l|}{ Recurrence } & \multicolumn{6}{|c|}{ Gastric Secretory Studies } \\
\hline & & & & & & \multirow[t]{2}{*}{ Symptoms } & \multirow[t]{2}{*}{ Site } & \multirow[t]{2}{*}{ Course } & \multicolumn{2}{|c|}{$\begin{array}{l}\text { Preoperative } A H T \\
\text { (m-equiv/hr) }\end{array}$} & \multicolumn{2}{|c|}{$\begin{array}{l}\text { Postoperative } A H T \\
\text { (m-equiv/hr) }\end{array}$} & \multirow[t]{2}{*}{$\begin{array}{l}\text { Insulin } \\
\text { Test }\end{array}$} & \multirow{2}{*}{$\begin{array}{l}\text { Retentio } \\
\text { in } \\
\text { Aspirate }\end{array}$} \\
\hline & & & & & & & & & $\begin{array}{l}\text { Basal } \\
\text { Secretion }\end{array}$ & $M A O$ & $\begin{array}{l}\text { Basal } \\
\text { Secretion }\end{array}$ & $M A O$ & & \\
\hline 1 & $\mathbf{F}$ & 60 & $\begin{array}{l}\text { Truncal } \\
\text { vagotomy and } \\
\text { two-layer } \\
\text { pyloroplasty }\end{array}$ & $\begin{array}{l}\text { Slight } \\
\text { dyspepsia }\end{array}$ & 3 wk & Haematemesis & $\begin{array}{l}\text { sesser curve } \\
\text { (subacute) }\end{array}$ & $\begin{array}{l}\text { Died from } \\
\text { bleeding }\end{array}$ & & & & & & \\
\hline 2 & $\mathbf{F}$ & 59 & $\begin{array}{l}\text { Truncal } \\
\text { vagotomy and } \\
\text { one-layer } \\
\text { pyloroplasty }\end{array}$ & None & $8 \mathrm{mth}$ & Dyspepsia & $\begin{array}{l}\text { Lesser curve } \\
\text { (chronic) }\end{array}$ & $\begin{array}{l}\text { Medical Rx }{ }^{7} \\
\text { Healed in } 3 / 12 \\
\text { Maintenance } \\
\text { carbenoxelone }\end{array}$ & $2^{7 \cdot 4}$ & $20 \cdot 2$ & $4 \cdot 5$ & $10 \cdot 0$ & - ve & None \\
\hline 3 & $\mathbf{F}$ & 43 & $\begin{array}{l}\text { Truncal } \\
\text { vagotomy and } \\
\text { Finney } \\
\text { pyloroplasty }\end{array}$ & $\begin{array}{l}\text { Retention, } \\
\text { dysphagia, } \\
\text { waterbrash, } \\
\text { diarrhoea }\end{array}$ & $8 \mathrm{mth}$ & $\begin{array}{l}\text { Dyspepsia, } \\
\text { dysphagia, } \\
\text { retention }\end{array}$ & $\begin{array}{l}\text { Lesser curve } \\
\text { (chronic) }\end{array}$ & $\begin{array}{l}\text { Medical Rx, } 1 \\
\text { improved } \\
\text { recurrence, } \\
\text { partial } \\
\text { gastrectomy }\end{array}$ & 1.5 & $13 \cdot 0$ & $\begin{array}{l}1.4 \\
2 \cdot 0\end{array}$ & $\begin{array}{l}2 \cdot 5 \\
3 \cdot 0\end{array}$ & $-v e$ & None \\
\hline 4 & $\mathbf{F}$ & 46 & $\begin{array}{l}\text { Truncal } \\
\text { vagotomy and } \\
\text { Heineke-Mikulicz } \\
\text { pyloroplasty }\end{array}$ & $\begin{array}{l}\text { None } \\
\mathrm{cz}\end{array}$ & $3 \mathrm{mth}$ & $\begin{array}{l}\text { Abdominal } \\
\text { pain, } \\
\text { vomiting }\end{array}$ & $\begin{array}{l}\text { Prepyloric } \\
\text { ulcer } \\
\text { (chronic) }\end{array}$ & $\begin{array}{l}\text { Medical Rx, } \\
\text { maintenance } \\
\text { carbenoxelone }\end{array}$ & & & $\begin{array}{l}2.5 \\
2.0\end{array}$ & $\begin{array}{l}2 \cdot 6 \\
2 \cdot 9\end{array}$ & $\begin{array}{l}-\mathrm{ve} \\
(\times 2)\end{array}$ & + \\
\hline 5 & $\mathbf{F}$ & 46 & $\begin{array}{l}\text { Selective } \\
\text { vagotomy and } \\
\text { one-layer } \\
\text { pyloroplasty }\end{array}$ & $\begin{array}{l}\text { Marked } \\
\text { retention }\end{array}$ & 3 wk & $\begin{array}{l}\text { Pain, } \\
\text { retention, } \\
\text { diarrhoea }\end{array}$ & $\begin{array}{l}\text { Lesser curve } \\
\text { (large) }\end{array}$ & $\begin{array}{l}\text { Medical Rx, } \\
\text { healed in } 2 / 12, \\
\text { maintenance } \\
\text { carbenoxelone }\end{array}$ & $0 \cdot 3$ & $7 \cdot 2$ & $\begin{array}{l}3 \cdot 9 \\
0 \\
2 \cdot 1\end{array}$ & $\begin{array}{l}8 \cdot 5 \\
1 \cdot 1 \\
3 \cdot 5\end{array}$ & & ++ \\
\hline 6 & $\mathbf{M}$ & 50 & $\begin{array}{l}\text { Truncal } \\
\text { vagotomy and } \\
\text { posterior gastro- } \\
\text { enterostomy }\end{array}$ & $\begin{array}{l}\text { Fullness after } \\
\text { meals }\end{array}$ & $2 \frac{1}{2} \mathrm{mth}$ & $\begin{array}{l}\text { Abdominal } \\
\text { pain, } \\
\text { haematemesis }\end{array}$ & $\begin{array}{l}\text { Lesser curve } \\
\text { (subacute) }\end{array}$ & $\begin{array}{l}\text { Died from } \\
\text { hepatic coma } \\
\text { due to bleeding }\end{array}$ & $3 \cdot 2$ & $57 \cdot 1$ & $2 \cdot 0$ & $35 \cdot 5$ & $-\mathrm{ve}$ & None \\
\hline 7 & $\mathbf{M}$ & 34 & $\begin{array}{l}\text { Truncal } \\
\text { vagotomy and } \\
\text { one-layer } \\
\text { pyloroplasty }\end{array}$ & None & $2 \mathrm{yr}$ & Melaena & $\begin{array}{l}\text { Prepyloric } \\
\text { ulcer } \\
\text { (chronic) }\end{array}$ & $\begin{array}{l}\text { Recurrent } 0 \\
\text { melaena, Polya } \\
\text { gastrectomy }\end{array}$ & 0.9 & $29 \cdot 2$ & $1 \cdot 2$ & 4.9 & $\begin{array}{l}\text { Late } \\
\text { +ve } \\
\text { response }\end{array}$ & None \\
\hline 8 & $\mathbf{M}$ & 38 & $\begin{array}{l}\text { Selective } \\
\text { vagotomy and } \\
\text { one-layer } \\
\text { pyloroplasty }\end{array}$ & None & $\pm 5 \mathrm{mth}$ & $\begin{array}{l}\text { Dyspepsia, } \\
\text { acute } \\
\text { abdominal } \\
\text { pain }\end{array}$ & $\begin{array}{l}\text { Prepyloric } \\
\text { ulcer } \\
\text { (chronic) }\end{array}$ & $\begin{array}{l}\text { Medical Rx, } 5 \\
\text { no healing, } \\
\text { partial } \\
\text { gastrectomy }\end{array}$ & $5 \cdot 4$ & $40 \cdot 0$ & 8.4 & $12 \cdot 9$ & $\begin{array}{l}\text { Late } \\
\text { +ve } \\
\text { response }\end{array}$ & None \\
\hline 9 & $\mathbf{M}$ & 42 & $\begin{array}{l}\text { Anterior } \\
\text { selective and } \\
\text { posterior truncal } \\
\text { vagotomy and } \\
\text { pyloroplasty }\end{array}$ & None & $10 \mathrm{mth}$ & $\begin{array}{l}\text { Abdominal } \\
\text { pain, } \\
\text { vomiting }\end{array}$ & $\begin{array}{l}\text { Prepyloric } \\
\text { ulcer } \\
\text { (chronic) }\end{array}$ & Medical Rx 2 & $2 \cdot 2$ & $39 \cdot 5$ & $2 \cdot 4$ & $23 \cdot 0$ & $\begin{array}{l}+ \text { ve } \quad 1 \\
\text { (5 } \\
\text { criteria) }\end{array}$ & None \\
\hline
\end{tabular}

responding poorly to medication and surgery is being considered. Pre- and postoperative augmented histamine tests were carried out in seven patients, only one of whom showed a postoperative value in excess of $50 \%$ of the preoperative values. One patient has persistent basal hypersecretion after surgery and the basal values were 'highish' in a number of others. An insulin test for vagal integrity was carried out in seven patients postoperatively. Four had no acid response to insulin and were considered to have complete vagal section, two had a positive acid response in the second hour after insulin suggesting an 'incomplete' but 'adequate' vagotomy (Ross and Kay, 1964; Bank et al, 1967), and the remaining one had an obviously incomplete vagotomy on all criteria (Bank et al, 1967). Only two patients showed evidence of gastric retention during the acid secretory studies, the gastric juice becoming clear simultaneously and the ulcer healing in one patient.

\section{DISCUSSION}

The development of gastric ulceration in the nine patients after vagotomy and drainage in the present series may have occurred by chance alone. Some 500 vagotomy and drainage procedures have been carried out for duodenal ulceration in the surgical wards of this hospital over the last five years and the incidence of gastric ulceration following the operation would thus be $1.8 \%$. Although this incidence would be high for the population at large, the chance association of gastric ulceration following vagotomy 
and drainage cannot be entirely discounted. Further, one of the patients in this series was taking salicylates and another had overt cirrhosis with porto-systemic shunting, both factors which may possibly be incriminated as predisposing causes of gastric ulceration occurring de novo. Gastric ulceration is also generally regarded as a disease of middleaged or elderly females and it is of interest that five of the patients in the present series were women over the age of 40 years.

Despite the foregoing, there are a number of mechanisms by which vagotomy and drainage could predispose to the subsequent development of gastric ulceration: first gastric stasis is a well-known early effect of vagotomy (Burge, 1964; Bank, Marks, and Louw, 1967); secondly, reflux gastritis may occur as a result of the drainage procedure; and thirdly, incomplete vagal section may enhance the development of gastric as well as recurrent duodenal or jejunal ulceration (Burge, 1964). Gastric ulceration has often been reported in association with gastric retention in patients with pyloric stenosis or after vagotomy without a drainage procedure, and it is also currently believed that gastric ulcers occurring concurrently with duodenal ulcers or duodenal scarring represent 'stasis ulceration' from occult or overt pyloric hold-up induced by the duodenal lesion (Carman, 1918; Burge, 1964; Johnson, 1965). The mechanism by which gastric stasis causes gastric ulceration is speculative; the two most favoured theories being (a) the development of superficial or atrophic gastritis as a result of the retention or (b) the continued stimulation of the gastric antrum by the retained material with the resultant excessive release of antral gastrin and consequently an augmented phase of acid secretion (De la Rosa, Linares, Woodward, and Dragstedt, 1964; Dragstedt, Camp, and Fritz, 1949; Oberhelman, 1964). In 1958 Woodward reported three patients with gastric stasis after vagotomy and pyloroplasty for duodenal ulcer, two of whom developed gastric ulceration and one antral gastritis. Burge, in a 10-year follow up after vagotomy and drainage noted a $0.8 \%$ gastric ulcer rate when the vagotomy was combined with a gastroenterostomy, and a $2 \cdot 3 \%$ gastric ulcer rate with pyloroplasty (Burge, 1964).

Burge contends that gastric ulceration following vagotomy and pyloroplasty is always due either to a transient loss of gastric motor function after the vagotomy, the ulcer resolving with the improvement in gastric tone, or to a badly made pyloroplasty or persistent duodenal stenosis (Burge, 1966). Furthermore, Buchler (1964) found the gastric emptying time to be prolonged after vagotomy and pyloroplasty.

Three of the patients in the present series had postoperative gastric stasis; in two of them the retention was marked requiring prolonged postoperative treatment or readmission to hospital, and the third patient complained of fullness after meals for a short period. However, only one of these patients developed the gastric ulcer during the phase of gastric stasis. The ulcer occurred two-anda-half and eight months later in the other two at a time when the fasting gastric aspirate was clear and the barium meals showed an adequately functioning pyloroplasty or gastroenterostomy with unimpaired gastric emptying. The remaining six had no clinical or radiological evidence of overt gastric stasis, and the time of onset of the ulcer varied from three weeks to two years.

While more refined and subtle techniques (Hunt and Spurrel, 1951; Horton, Ross, and Darling, 1965; Griffiths et al, 1968) may have shown delayed gastric emptying or hypomotility in all nine of our patients, it was evident that gastric ulceration might occur in the absence of overt gastric stasis and with a seemingly adequately functioning drainage procedure. The continued high basal secretion after operation in one male patient in this series, who developed a prepyloric ulcer, in the absence of detectable gastric retention, suggests that antral hyperfunction may occasionally occur either due to undetectable stasis or reflux alkalinization of the antrum.

The association of gastric ulceration and 'gastritis' has been recognized for many years and gastritic changes in the mucosa surrounding gastric ulcers is almost invariably present (Magnus, 1952; Ball and James, 1961 ; MacKay and Hislop, 1966). Whether these changes are propter hoc or post hoc remains undecided but a number of workers believe antral gastritis to be the main predisposing factor in the development of gastric ulceration. Du Plessis (1965) and Capper (1967), in both experimental and clinical studies, have found a high incidence of antral atrophic gastritis in association with gastric ulceration, the gastritis being attributed to reflux of duodenal contents into the stomach (Lawson, 1964). The comment that gastric ulcers are 'anastomotic' in the sense that they occur in the junctional zone of the pyloric gland area immediately adjacent to the acidbearing area has gained widespread acceptance (Oi, Oshida, and Sugimura 1959; Marks and Shay, 1959). We have noted a higher incidence of superficial and atrophic gastritis in patients undergoing vagotomy and gastroenterostomy (Bank et al,1967); this may be related to freer reflux of duodenal contents into the stomach after the drainage procedure. On the other hand, Melrose, Russell, and Dick (1964) found little difference between the gastric histology after surgery when compared with that in unoperated cases 
(Joske, Finckh, and Wood, 1955). In the present series gastritis was found in the two patients subjected to gastrectomy and circumstantial evidence of gastritis was found on gastrocamera studies in a third. Postmortem autolysis precluded a definite histological label of gastritis in the two patients who died of haemorrhage.

While recurrent duodenal or jejunal ulceration is almost invariably associated with incomplete vagal section after vagotomy and drainage (Ross and Kay, 1964; Burge, 1964; Bank et al, 1967), vagal factors would appear to be unimportant in the development of recurrent gastric ulceration. Of seven patients in this series on whom insulin tests were carried out postoperatively four had a negative insulin response by all criteria (Hollander, 1948; Kay, 1967; Bank et al, 1967) and only one had a positive insulin response by all criteria. There was no obvious correlation between the level of postoperative acid secretion and the site of the ulcer in the stomach.

The occurrence of gastric ulceration after vagotomy and drainage for duodenal ulcer inevitably poses the problem of the advisability of these procedures or drainage alone in preference to gastrectomy in the management of gastric ulceration. Both the above methods have been re-advocated as the treatment of choice for gastric ulceration after a lull of some 20 years (Burge, 1964 and 1966; Dragstedt, 1966; Kennedy and George, 1967). An adequate drainage procedure, whether combined with a vagotomy or not, will certainly produce healing of the vast majority of gastric ulcers, but it should be remembered that bed rest alone, or alkalis, diet, anticholinergics, or carbenoxolone will produce equally gratifying initial results. We have previously reported that nearly all gastric ulcers can be healed on a medical regime if treatment is continued for long enough, and it is the high recurrence rate that is disturbing rather than the diagnostic accuracy or the initial healing (Bank et al, 1967). Recently, Woodward, Eisenberg, and Dragstedt (1967) reported three patients with recurrent gastric ulcers after pyloroplasty, two of whom died, and another patient who required a gastrectomy for a recurrent gastric ulcer after vagotomy, drainage, and wedge resection of a previous gastric ulcer. Herrington (1967) noted three recurrences shortly after vagotomy and pyloroplasty in 10 patients treated for benign gastric ulceration. It is obvious that the results of vagotomy and drainage for gastric ulcer must await further assessment and include a follow up of at least a few years. At present it is our policy to recommend Billroth I gastrectomy for the vast majority of patients with lesser curve gastric ulceration and to reserve vagotomy, drainage, with or without wedge resection, and postoperative medical treatment for unduly thin individuals, or in the face of mitigating circumstances such as pulmonary tuberculosis, emphysema, or cardiac disease. Dragstedt has suggested a large dependent gastroenterostomy in an attempt to minimize gastric stasis and antral hyperfunction as the drainage procedure of choice if vagotomy and drainage is contemplated for gastric ulceration (Dragstedt, 1952).

In conclusion, the pathogenesis of gastric ulceration after vagotomy and drainage may be regarded as a summation of factors, one or more of which may be the initiating factor in any invididual patient. In the present series the age and sex of the patients, gastric hypomotility, and hyperfunction of the antrum, reflux gastritis, the ingestion of salicylates, and porto-systemic shunting may each have played a role. It does not seem that one lone factor can explain the ulceration in all the patients.

Although the incidence of recurrent gastric ulceration after vagotomy and pyloroplasty is low when compared with recurrent duodenal or jejunal ulceration this complication should be borne in mind in patients presenting with dyspepsia, abdominal pain, or bleeding after surgery, particularly if the vagotomy appears to be complete or adequate. Our results also suggest that chronic gastric ulceration following vagotomy and drainage carries a particularly poor prognosis for continued healing on medical treatment alone.

\section{SUMMARY}

The case records of nine patients who developed gastric ulceration after vagotomy and drainage for duodenal ulceration are presented. The drainage procedures consisted of pyloroplasty in eight and a posterior gastroenterostomy in the remaining one.

The possible mechanism responsible for the gastric ulceration is discussed and it is suggested that this complication should be borne in mind in patients presenting with dyspepsia, abdominal pain, or bleeding after vagotomy and drainage.

This study was supported by the South African Council for Scientific and Industrial Research, the Ben May Gastroenterology Research Fund, and the Herman Staff Research Fund.

We wish to thank Dr J. G. Burger, Medical Superintendent, for permission to publish the cases.

REFERENCES

Ball, P. A. J., and James, A. H. (1961). The histological background to gastric ulcer. Lancet, 1, 1365-1367. 
Bank, S., Marks, I. N., and Louw, J. H. (1967). Histamine- and insulin-stimulated gastric acid secretion after selective and truncal vagotomy- Gut,8, 36-41.

—, - Palmer, P. E. S., Groll, A., and van Eldik, E. (1967). A trial of carbenoxolone sodium in the treatment of gastric ulceration. S. Afr. med. J., 41, 297-300.

Bockus, H. L. (1964). Gastroenterology, 2nd ed., vol. 2, p. 676. Philadelphia and London.

Buchler, K. (1964). Report to the British Society of Gastroenterology, Hammersmith. (Cited by Capper, W. M. (1967). Ann. roy. Coll. Surg. Engl., 40, 21).

Burge, H. (1964). Vagotomy, p. 100. Arnold, London.

(1966). The aetiology of benign lesser curve gastric ulcer: vagotomy and pyloroplasty in its treatment. Ann. roy. Coll. Surg. Engl., 38, 349-369.

Capper, W. M. (1967). Factors in the pathogenesis of gastric ulcer. Ibid., 40, 21-35.

Carman, R. D. (1918). Roentgen diagnosis of concurrent gastric and duodenal ulcer. Amer. J. Roentgenol., 4, 552-554.

De la Rosa, C., Linares, C. A., Woodward, E. R., and Dragstedt, L. R. (1964). Experimental gastric ulcer produced by pyloric stenosis. Arch. Surg., 88, 927-931.

Dragstedt, L. R. (1952). Vagotomy in the treatment of peptic ulcer. Surg. Clin. N. Amer., 32, 29-34.

- (1953). Is gastric ulcer due to hyperfunction or dysfunction of the gastric antrum? Surg. Gynec. Obstet.,97, 517-519.

- (1956). A concept of the aetiology of gastric and duodenal ulcers. Gastroenterology, 30, 208-220.

- (1966). Vagotomy in the surgical treatment of peptic ulcer. Surg. Clin. N. Amer., 46, 1153-1162.

- Camp, E. H., and Fritz, J. M. (1949). Recurrence of gastric ulcer after complete vagotomy. Ann. Surg., 130, 843-854.

$\longrightarrow$, and Owens, F. M., Jr. (1943). Supra-diaphragmatic section of the vagus nerves in treatment of duodenal ulcer. Proc. Soc. exp. Biol. (N.Y.), 152-154.

Du Plessis, D. J. (1965). Pathogenesis of gastric ulceration. Lancet, 1, 974-978.

Griffith, G. H., Owen, G. M., Campbell, H., and Shields, R. (1968). Gastric emptying in health and in gastroduodenal disease. Gastroenterology, 54, 1-7.

Herrington, J. L., Jr. (1967). In discussion of paper by Woodward et al, Amer. J. Surg., 113, 11.
Hollander, F. (1948). Laboratory procedures in the study of vagotomy. Gastroenterology, 11, 419-425.

Horton, R. E., Ross, F. G. M., and Darling, G. H. (1965). Determination of the emptying-time of the stomach by use of entericcoated barium granules. Brit. med. J., 1, 1537-1539.

Hunt, J. N., and Spurrell, W. R. (1951). The pattern of emptying of the human stomach. J. Physiol. (Lond.), 113, 157-168.

Johnson, H. D. (1965). Gastric ulcer: classification, blood group characteristics, secretion patterns and pathogenesis. Ann. Surg., 162, 996-1004.

Joske, R. A., Finckh, E. S., and Wood, I. J. (1955). Gastric biopsy: a study of 1000 consecutive successful gastric biopsies. Quart. J. Med., 24, 269-294.

Kay, A. W. (1967). Memorial Lecture: an evaluation of gastric acid secretion tests. Gastroenterology, 53, 834-844.

Kennedy, T., and George, J. D. (1967). Conservative surgery in the treatment of benign gastric ulcer. (Abstr.). Gut, 8, 632.

Lawson, H. H. (1964). Effect of duodenal contents on the gastric mucosa under experimental conditions. Lancet, 1, 469-472.

Mackay, I. R., and Hislop, I. G. (1966). Chronic gastritis and gastric ulcer. Gut., 7, 228-233.

Magnus, H. A. (1952). Gastrit is. In Modern Trends in Gastroenterology, edited by F. Avery Jones, 1st Saries, 323-351. Butterworth, London.

Marks, I. N., and Shay, H. (1959). Observations on the pathogenesis of gastric ulcer. Lancet, 1, $1107-1111$.

Melrose, A. G., Russell, R. I., and Dick, A. (1964). Gastric mucosa structure and function after vagotomy. Gut, 5, 546-549.

Oberhelman, H. A., Jr. (1964). The role of the gastric antrum in peptic ulcer. Monogr. surg. Sci., 1, 347-372.

Oi, M., Oshida, K., and Sugimura, S. (1959). The location of gastric ulcer. Gastroenterology, 36, 45-56.

Ross, B., and Kay, A. W. (1964). The insulin test after vagotomy. Ibid., 46, 379-386.

Stitt, R. B., O'Sullivan, P. M., and Currie, D. J. (1966). Gastric ulcer a complication of vagotomy and pyloroplasty. Canad. med. Ass. J., 94, 244-245.

Woodward, E. R. (1958). Hyperfunction of gastric antrum following vagotomy and pyloroplasty. Arch. Surg., 77, 289-293.

Woodward, E. R., Eisenberg, M. M., and Dragstedt, L. R. (1967) Recurrence of gastric ulcer after pyloroplasty. Amer. J. Surg., 113, 5-12. 